\title{
Climate Change Trends in Colombia: A Case Study in Facatativá, Cundinamarca
}

\author{
Daniel Armando Robledo-Buitrago ${ }^{1,2^{*}}$, Manuel Francisco Polanco-Puerta ${ }^{1}$, Miguel De Luque-Villa ${ }^{2,3}$, Mauricio Mesa- \\ Caro $^{2}$, Carlos Alberto Calderón-Ricardo ${ }^{4}$ \\ ${ }^{1}$ Facultad de Ciencias Contables, Económicas y Administrativas, Universidad de Manizales, Cra 9 a \# 19-03, Manizales \\ 170001, Colombia \\ ${ }^{2}$ Facultad de Ciencias Agropecuarias Grupo Cundinamarca Agroambiental, Universidad de Cundinamarca, Calle 14 Av 15 , \\ Facatativá 253051, Colombia \\ ${ }^{3}$ Facultad de Estudios Ambientales y Rurales, Grupo Ecología y Territorio, Pontificia Universidad Javeriana, Bogotá D.C., \\ Carrera 7 No. 40-62, Bogotá 110231, Colombia \\ ${ }^{4}$ Facultad de Ciencias Agropecuarias Grupo Agrociencia, Universidad de Cundinamarca, Calle 14 Av 15, Facatativá 253051, \\ Colombia
}

Corresponding Author Email: drobledo@ucundinamarca.edu.co

https://doi.org/10.18280/ijsdp.160314

Received: 15 February 2021

Accepted: 20 May 2021

\section{Keywords:}

climate change, trends, temperature, precipitation, Colombia

\begin{abstract}
Climate change modifies the average climate behavior over a long period, generated by natural phenomena or anthropogenic causes. This change has an important impact on climate variables, such as temperature and precipitation, worldwide but also has various effects on the local scale. The purpose of this research was to determine climate behavior and the magnitude of climate change in the last 30 years in the municipality of Facatativá, Cundinamarca. Precipitation and temperature were analyzed using data from climatological stations around Facatativá, which belong to the Instituto de Hidrología, Meteorología y Estudios Ambientales (IDEAM) and the Corporación Autónoma Regional de Cundinamarca. These data provided the average temperature in this municipality, between $9.2^{\circ} \mathrm{C}$ and $14.0^{\circ} \mathrm{C}$, with an increasing trend between $0.00^{\circ} \mathrm{C} / \mathrm{yr}$ to the west and $0.03^{\circ} \mathrm{C} / \mathrm{yr}$ to the east of the municipality. The Precipitation ranged between $781 \mathrm{~mm} / \mathrm{yr}$ and $1200 \mathrm{~mm} / \mathrm{yr}$, with an increasing trend of between $3.0 \mathrm{~mm} / \mathrm{yr}$ in the west and $12.0 \mathrm{~mm} / \mathrm{yr}$ in the northwest.
\end{abstract}

\section{INTRODUCTION}

Climate has been changing for decades. Since the end of the 20th century, warm periods have occurred more frequently, and the average temperature in recent years has been the highest in centuries [1], Different studies have observed that increases in the intensity and frequency of extreme events are associated with climate change and variability [2-4]; There is proof that climate change is already occurring and may be irreversible [5].

This change may be partly related to natural causes, but it is undeniable that, since the industrial revolution, climate change has become more evident, resulting from anthropic factors [6]. Factors that promote climate change include the emission of aerosols, carbon dioxide, methane, and chlorofluorocarbons into the atmosphere, the effects of clouds, volcanic activity, changes in albedo and terrestrial reflection, changes in the magnetic field, air pollution, and the amount of solar energy that reaches the earth, among others [6].

Although the effects of climate change on temperature and precipitation are different depending on the region of the world, the impacts of this phenomenon are intensifying, such as water scarcity, intensification and greater frequency of natural threats such as floods, fires, and hurricanes, melting of polar ice caps, rising sea level, decreased crop yields, and proliferation of pests, among others [7].

In this sense, developing countries such as Colombia are more vulnerable to the impacts of climate change since there is a limited institutional capacity, reduced technologies and limited access to financial resources [8]. Elucidating the temporal and spatial climate and its trends is the first step in the development of mitigation and adaptation strategies and mechanisms framed within sustainable development goals.

It is expected that, by 2040, the average temperature in Colombia will have increased by $0.9^{\circ} \mathrm{C}$, and precipitation will have changed by between $-14 \%$ to $8 \%$, depending on the region, with direct, negative effects on water availability, health, and agriculture. These effects are related to the resilience capacity of the territory [9].

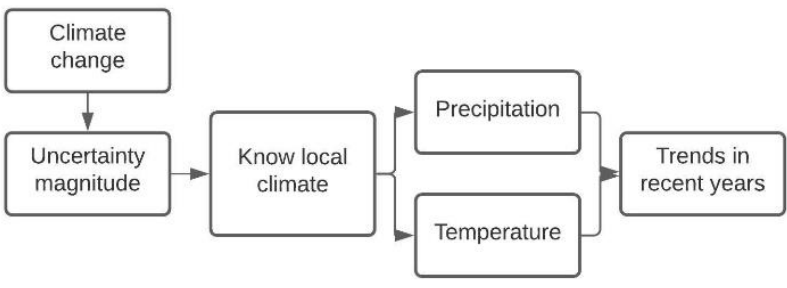

Figure 1. Objective conceptualization

Given the degree of uncertainty for the magnitude of climate change in different parts of the world, this research sought to elucidate the spatial and temporal behavior of the climate in Facatativá, determined by precipitation and temperatures, and 
identify the trends of changes in these variables in recent years (Figure 1).

\section{MEDOTOLOGY}

\subsection{Study area}

The municipality of Facatativá is located in the Department of Cundinamarca, at $74^{\circ} 20^{\prime} 24.753^{\prime \prime} \mathrm{W}$ and $4^{\circ} 49^{\prime} 57.362^{\prime \prime} \mathrm{N}$, with an average elevation of 2,586 meters above sea level. It has an area of $158.8 \mathrm{~km}^{2}$, an urban population of 151,275 inhabitants, and a rural population of 10,931 inhabitants.

For the data analysis, weather stations in the municipality and surrounding areas were used, within a radius of up to 40 $\mathrm{km}$ from the municipal limit of Facatativá, as shown in Figure 2.

\subsection{Data processing}

Data from 13 weather stations (Table 1) belonging to the Corporación Autónoma Regional de Cundinamarca (CAR) and the Instituto de Hidrología, Meteorología y Estudios Ambientales (IDEAM) were used.

Information was requested on a monthly scale for a 30 -year series (1989 to 2018), monitoring total precipitation, average temperature, minimum temperature, and maximum temperature, according to the availability established by the station characteristics and the statistical series provided by the entities. This information was added to spreadsheets, where a consistency analysis was performed using Grubbs test, which identified outliers in the data series according to Eq. (1).

$$
G=\frac{\left|x_{n}-\bar{x}\right|}{\delta}
$$

where:

$x_{n}$ : Value of evaluated data series

$\bar{x}$ : Data series mean

$\delta$ : Standard deviation

G: Critical Grubbs value for a number of observations $n=$ 360 and a significance level over $5 \%, \mathrm{G}<3.9194$.
Once the missing and inconsistent values were determined, the series were filled and corrected using the linear correlation method, generating a scatter plot between two stations, and the proportions method [10, 11] using Eq. (2). Finally, the monthly and annual average data were definitively tabulated.

$$
X=\frac{X_{1} \times P f}{P a-X_{1}}
$$

where:

$\mathrm{X}$ : Missing or inconsistent monthly precipitation.

$\mathrm{X} 1$ : Missing mean monthly rain.

Pf: Total annual precipitation with the month missing.

Pa: Mean total annual precipitation.

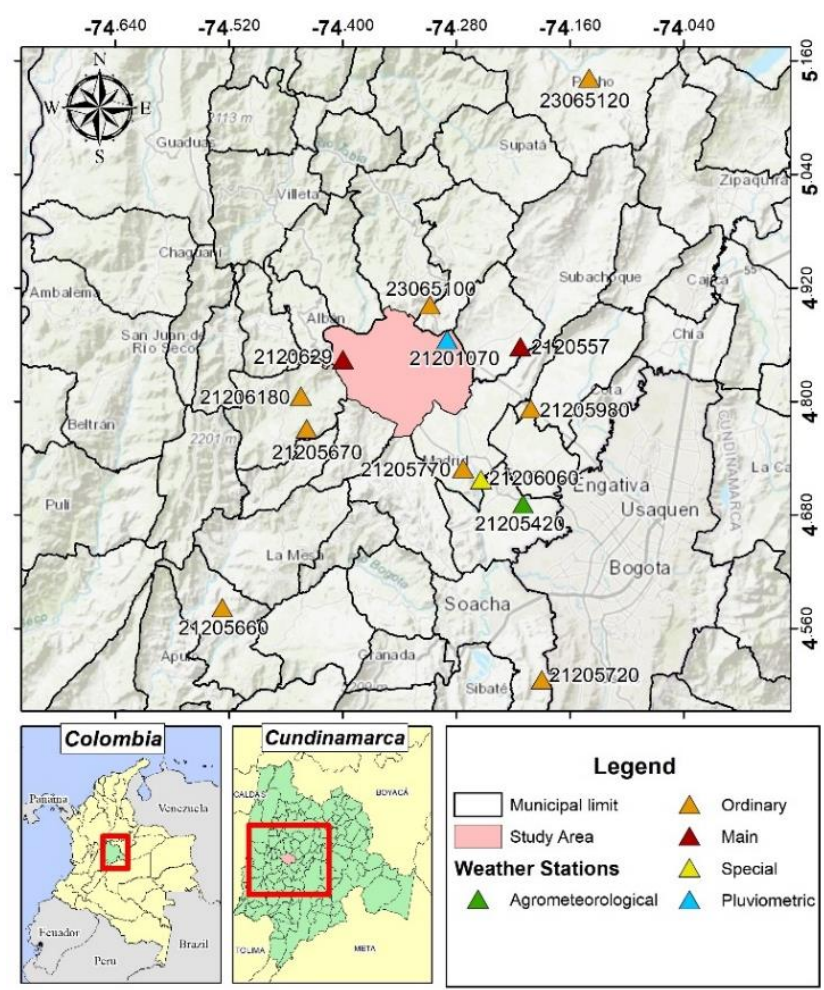

Figure 2. The geographical location of Facatativá and the weather stations

Table 1. Analyzed weather stations

\begin{tabular}{cccccc}
\hline Code & Name & Municipality & Altitude (mamsl) & Latitude & Longitude \\
\hline 21205670 & La Florida & Anolaima & 1915 & 4.771 & -74.438 \\
21206060 & Casablanca & Madrid & 2575 & 4.717 & -74.253 \\
21205770 & Base Aérea Madrid & Madrid & 2550 & 4.729 & -74.272 \\
21205980 & Granja Providencia & Tenjo & 2560 & 4.792 & -74.201 \\
21205420 & Tibaitata & Mosquera & 2543 & 4.691 & -74.209 \\
21201070 & El Corazón & Facatativá & 2845 & 4.865 & -74.289 \\
21206180 & Primavera D Matima & Anolaima & 1850 & 4.805 & -74.443 \\
21205660 & Las Mercedes & Anapoima & 810 & 4.582 & -74.527 \\
23065100 & Sabaneta & San Francisco & 2475 & 4.902 & -74.307 \\
21205720 & Granja San Jorge & Soacha & 2900 & 4.506 & -74.189 \\
23065120 & La Cabrera & Pacho & 1894 & 5.142 & -74.139 \\
2120629 & Venecia & Facatativá & 2686 & 4.844 & -74.399 \\
2120557 & La Primavera & El Rosal & 2623 & 4.858 & -74.212 \\
\hline \multicolumn{5}{c}{} &
\end{tabular}

\subsection{Data analysis}

ArcGIS 10.5 mapped the spatial distribution of precipitation (isohyets) with the means of the geostatistics module using interpolation through the weighted inverse distance method
(IDW) for the mean spatial distribution. The methodology proposed by Fries et al. [12] was used for the minimum and maximum temperature (isotherms), first determining the vertical thermal gradient with the relationship between height above sea level on the $\mathrm{X}$ axis and temperature on the $\mathrm{Y}$ axis, 
and using linear regression for the slope of the line formed by the trend line. The reference temperature was then determined, which simulated the behavior of this variable if the stations were at the same level, using Eq. (3):

$$
T \operatorname{Ref}=T+(\operatorname{Gr} \times(Z \operatorname{Ref}-Z E s t))
$$

where:

TRef: Reference temperature.

$\mathrm{T}$ : Maximum, minimum, or mean station temperature (according to the isothermal).

Gr: Vertical thermal gradient.

ZRef: Reference level, (intermediate altitude of the study zone in meters).

ZEst: Station altitude.

Next, a digital ASTER GDEM elevation model of the study area obtained from NASA's Earth Data platform (https://search.earthdata.nasa.gov/search) was loaded into the GIS software, along with a layer of points that represented the location of the climatological stations, appending the reference temperature data calculated in the previous step. This layer was used to generate a raster image with IDW interpolation, which used map algebra with the digital elevation model applying Eq. (4):

$$
T=T R e f+(G r \times(Z D E M-Z R e f))
$$

where:

T: Raster image with a total distribution of temperatures in the study area.

TRef: Raster image resulting from the interpolation of the reference temperatures.

Gr: Vertical thermal gradient.

ZMDE: Digital elevation model (MDE) ASTER GDEM.

Zref: Reference level used in Eq. (3).

Subsequently, the trends of the annual values of the average, minimum, maximum temperature and total precipitation were determined. To quantify the impact of climate change, scatter plots were made for each station, where the $\mathrm{X}$-axis corresponds to the years of study and the Y-axis, the mean temperature or total precipitation of the corresponding year, the slope of the trend line of each graph was determined by linear correlation, this slope is the magnitude of the change of each variable in each station. The results are shown in tables and maps.

\section{RESULTS AND DISCUSSION}

\subsection{Current average climate}

The analyzed time series (1989 to 2018) had average temperatures between $9.2^{\circ} \mathrm{C}$ in the high areas (above 3,000 masl) and $14.0^{\circ} \mathrm{C}$ in the low areas (approximately 2,550 masl), with a total mean of $12.5^{\circ} \mathrm{C}$ throughout the municipality. The average minimum temperatures in Facatativá ranged between $2.4^{\circ} \mathrm{C}$ and $7.8^{\circ} \mathrm{C}$, while the maximums were in the order of $14.0^{\circ} \mathrm{C}$ and $20.1^{\circ} \mathrm{C}$ (Figure 3 ), making a cold thermal floor.

The average rainfall was $922 \mathrm{~mm} /$ year, with $781 \mathrm{~mm} / \mathrm{year}$ in the southern sector, determined by proximity to the Mondoñedo - Zabrinsky sector, which has a subxerophytic ecosystem, corresponding to an Andean azonal Orobiome on the Altiplano Cundiboyacense. Orobiomes are bioclimatic zones determined by the incidence of mountains that affect the water regime [13, 14], The northern zone sees $1200 \mathrm{~mm} / \mathrm{year}$, produced by the dynamics between cloud masses in the Magdalena Valley and the Cordillera Occidental, due to the rise of hot air up the slope, later when it cools it condenses causing orographic rains [15], this spatial behavior of the precipitation can be seen in Figure 4.

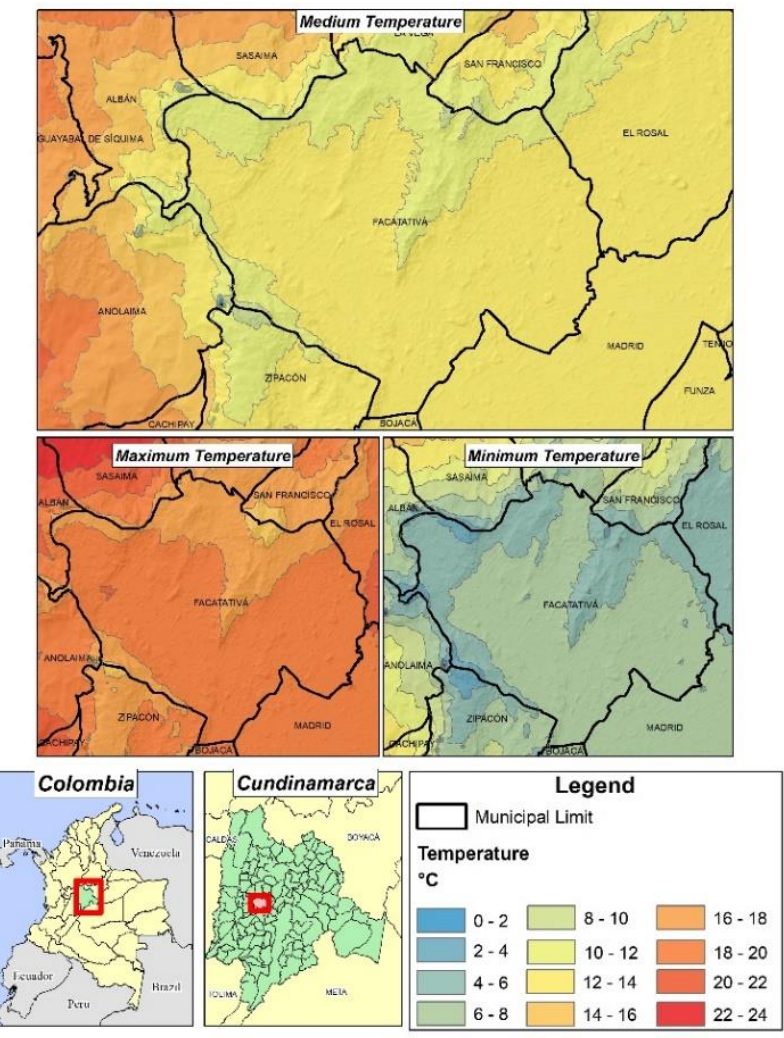

Figure 3. Geographic distribution of the mean, maximum and minimum annual temperature

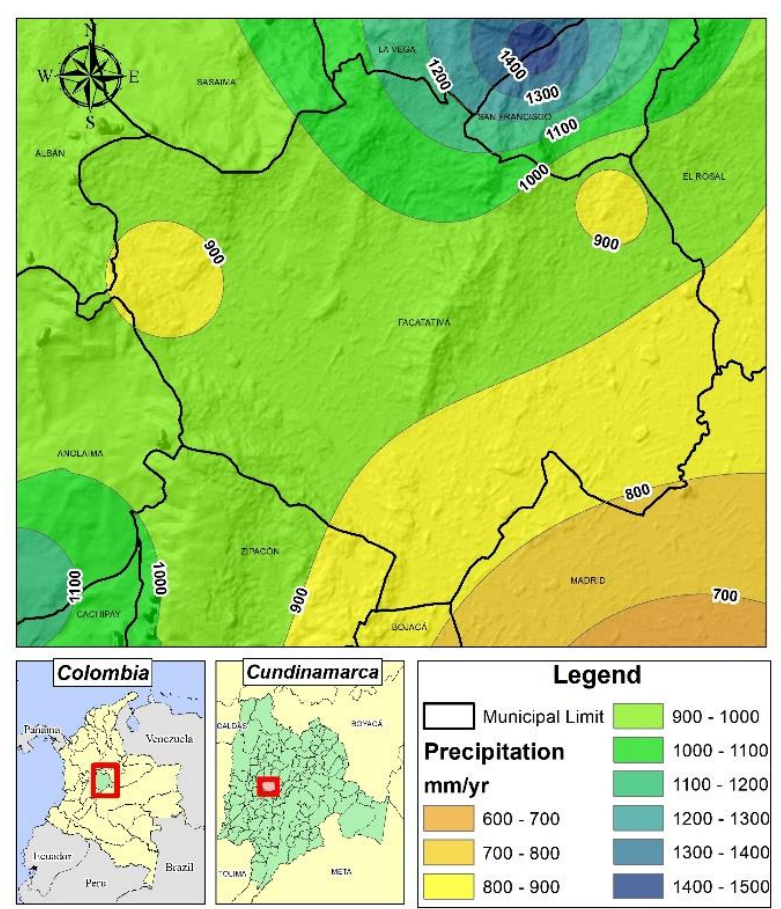

Figure 4. Geographic distribution of total annual precipitation 
For the temporal behavior of the variables, it was observed that precipitation at the stations selected for this study presented a bimodal regime, with rainy seasons from March to June and October to December, and low rainfall January to February and July to September, as can be seen in Figure 6. It was also observed that all seasons saw an abrupt, sustained reduction of precipitation for three months. The second dry season of the year (July to September) saw less than 70 $\mathrm{mm} / \mathrm{month}$. In Facatativá, the first dry season is usually less strong, while the second one is usually longer and more intense, with rainfall that does not exceed $50 \mathrm{~mm} /$ month (Figure 6), impacting access to surface water since the flow of water is drastically reduced, this behavior is mainly influenced by the movement of the intertropical confluence zone -ITCZ- which determines the seasonality of precipitation in the equatorial belt (Figure 5), taking into account that facatativá is located at a latitude close to $5^{\circ} \mathrm{N}$.

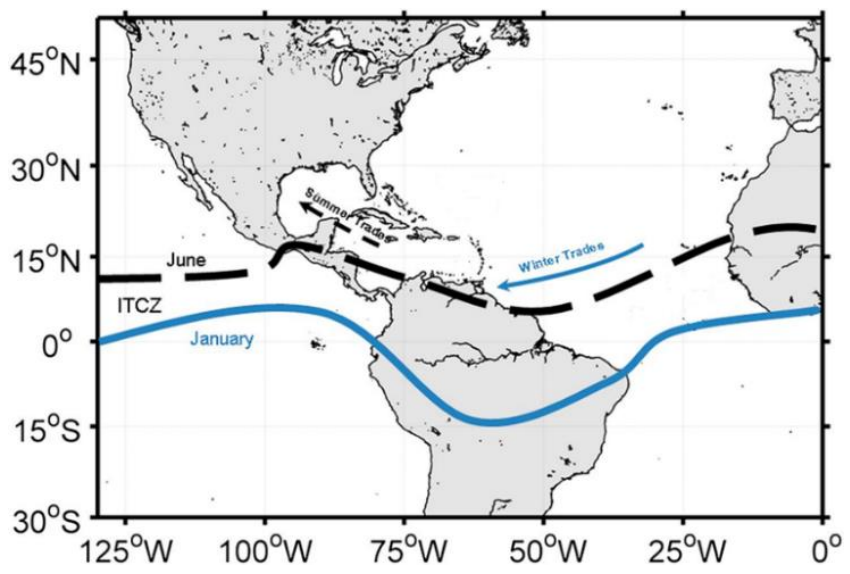

Figure 5. Average seasonal positions of intertropical confluence zone [16]

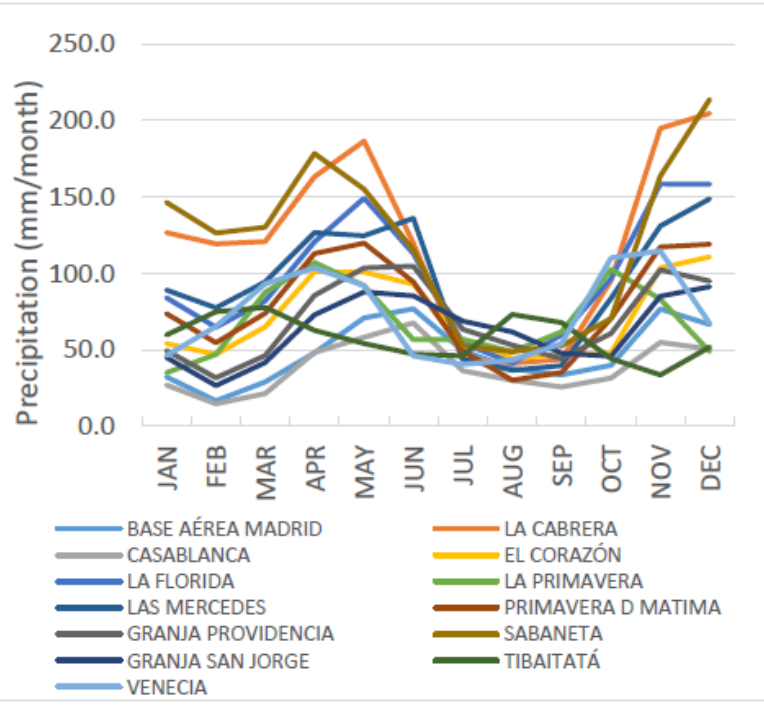

Figure 6. Interannual precipitation in the analyzed stations

The average monthly temperature did not show marked trends in the lower stations (La Cabrera, La Florida, and Primavera D Mattima), with temperatures above $16^{\circ} \mathrm{C}$. However, as seen in Figure 7, the stations with average temperatures below $15^{\circ} \mathrm{C}$ were grouped by this tendency, presenting similar weather conditions as the Municipality of Facatativá because they shared similar altitudes. These stations had a marked behavior with higher average temperatures in the first semester of the year, peaking in May, with a subsequent decrease until July, when the average temperature stabilized until December, with a small increase towards the months of September and October. This seasonal variability resulted from the annual oscillation of the Sun between the tropics, which is derived from the translational movement and precession of the Earth, with the Sun's Zenith in the equatorial zone where solar rays are perpendicular twice a year with a slight delay of the equinoxes (March 21 and September 21). The result is two insolation peaks in the intertropical zone [17].

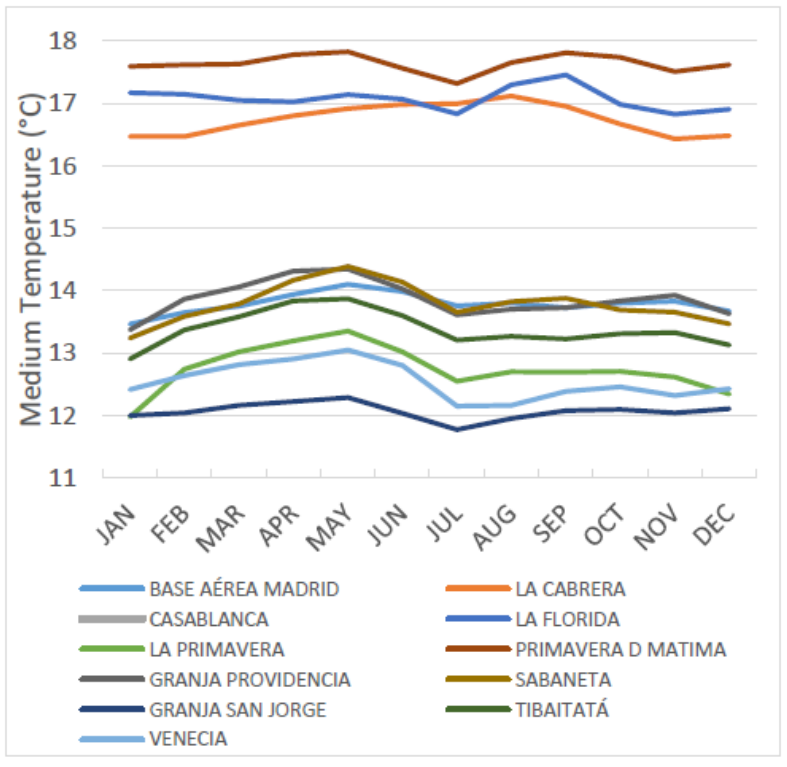

Figure 7. Interannual medium temperatures in the analyzed stations

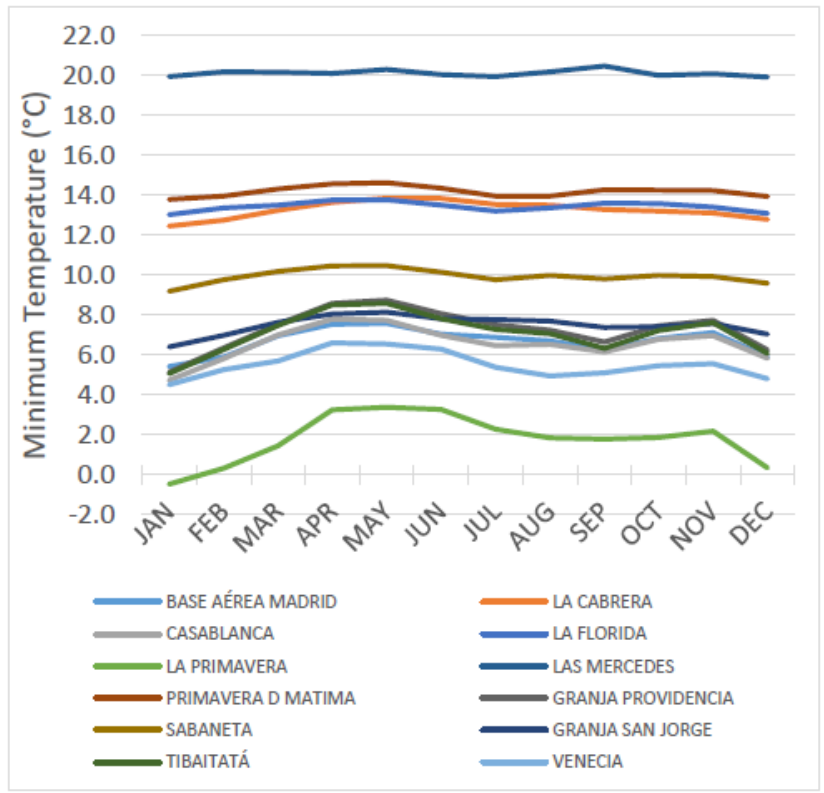

Figure 8. Interannual minimum temperatures in the analyzed stations

On the other hand, a marked seasonality was observed in the minimum temperatures (Figure 8), with lower temperatures in the months of December-January and August-September, coinciding with the highest values of the maximum temperatures as observed in Figure 9. This result is explained by the movement of cloud masses since the indicated months 
tend to have less cloudiness, which facilitates the direct entry of solar rays during the day, heating the air. On the contrary, at night, a faster output of solar radiation occurs through thermal inversion, one of the main causes of radiation frost, which is common in this region mainly in January [18]; In this month, the flat part of the municipality $(<2,600$ masl $)$ is most susceptible to these phenomena, reaching lower temperatures, between 4 and $6^{\circ} \mathrm{C}$ (Figure 8), with absolute minimums of up to $-3.5^{\circ} \mathrm{C}$, as recorded in the La Primavera station in January 2013.

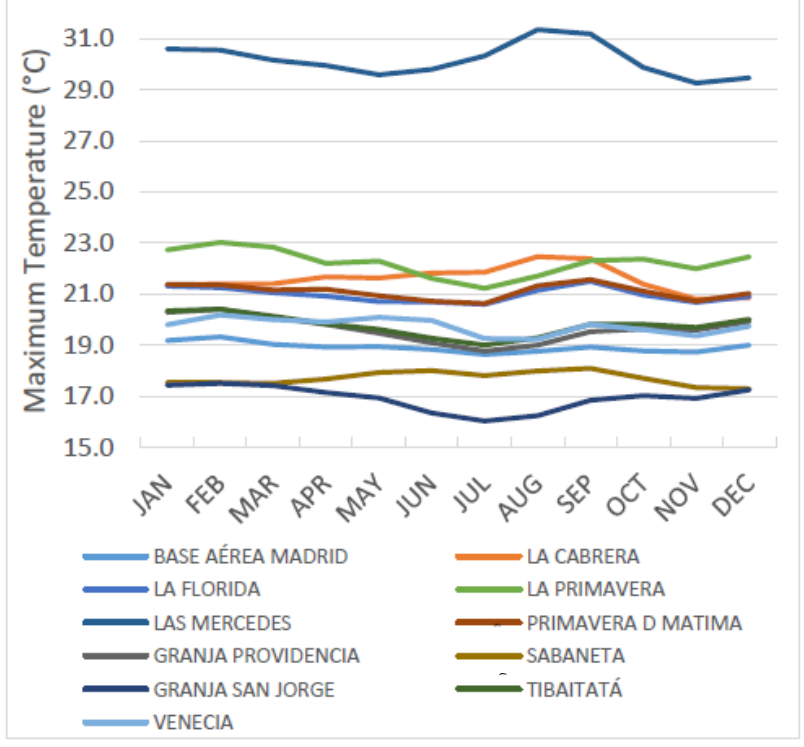

Figure 9. Interannual maximum temperatures in the analyzed stations

\subsection{Climate change trends}

Once the average climatic conditions of the municipality were known, the trends of the annual series reported for the selected stations were analyzed. Even though climate change is a global phenomenon, such as increased temperatures that acidify oceans and melting of mountainous glaciers, among others, there are local effects [19], such as alteration of climatic patterns that leads to increased or decreased temperatures and precipitation, with a consequent modification of other related variables. An analysis of these variables on a larger scale is required to generate adequate solutions for adaptation and territorial planning [20].

Analyzing 13 weather stations for precipitation and 11 for temperature showed different trends for the analyzed territory according to the regressions (Figure 10 to Figure 13 shows regressions for Base aérea Madrid and La Florida stations). The general trend of the stations in Facatativá and surrounding municipalities presented a progressive increase in the mean, minimum and maximum temperatures, as well as an increase in precipitation, as observed in Table 2 . There was a maximum gradient of increase in the average, maximum, and minimum temperatures in La Primavera station, but there were also specific inclinations for reductions in the average and maximum annual temperatures (Venecia and Base aérea Madrid), as well as a slight reduction in total precipitation (La Florida and Sabaneta). These diverse trends and the decrease in temperature and precipitation in some seasons resulted from factors such as altitude, relief, soil moisture, land cover, and variability in the phenomenon known as El Niño Southern
Oscillation -ENSO-, with specific effects of climate change that do not modify the general trend of the region or the increase in global temperatures [21-23]. The increase in precipitation was directly linked to the general increase in temperature in the region since a warmer atmosphere will have a greater capacity to store humidity, likewise, evapotranspiration increases, which more water is available in the atmosphere for precipitation.

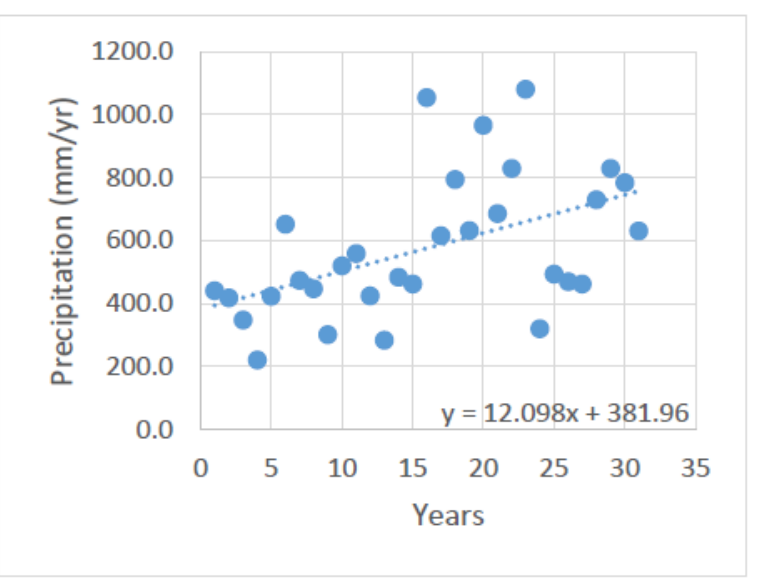

Figure 10. Base aérea Madrid (21205770) Total annual precipitation trend

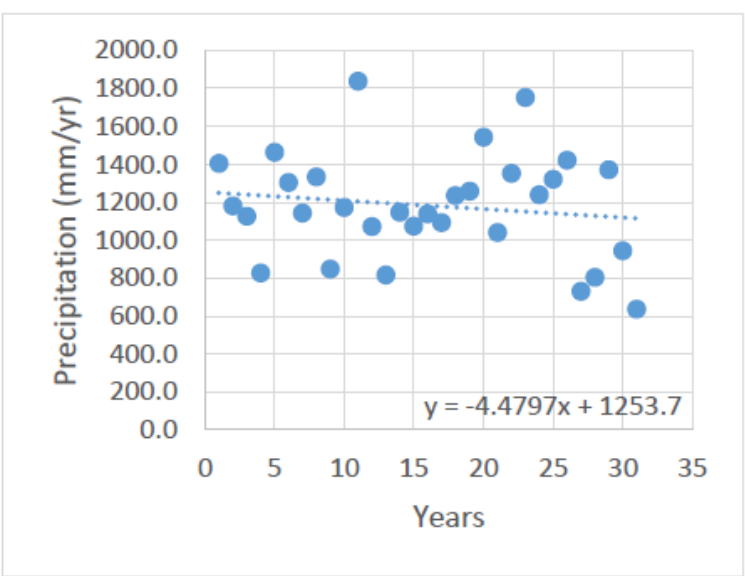

Figure 11. La Florida (21205670) Total annual precipitation trend

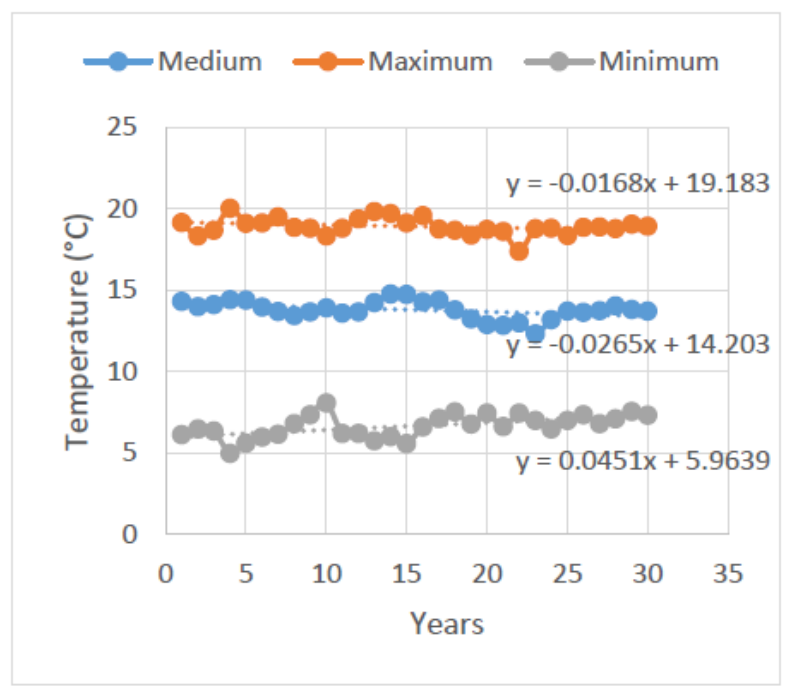

Figure 12. Base aérea Madrid (21205770) maximum, medium, and minimum temperature trends 


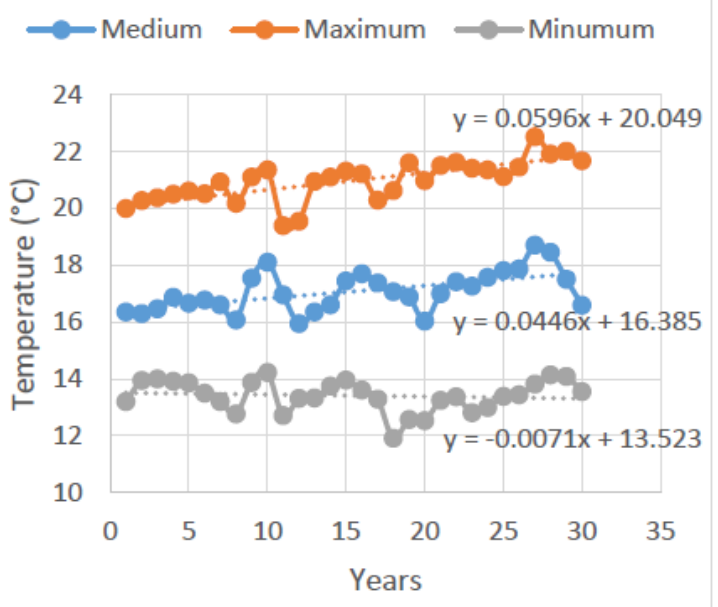

Figure 13. La Florida (21205670) maximum, medium, and minimum temperature trends

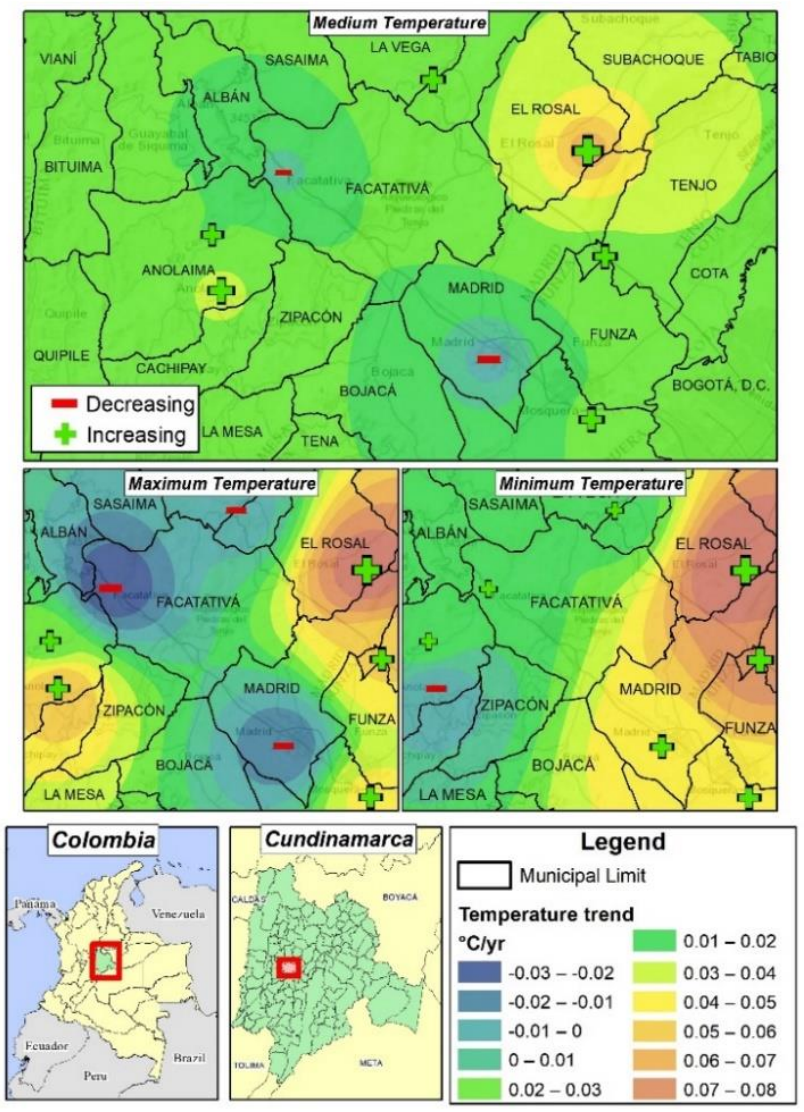

Figure 14. Medium, maximum, and minimum temperature trends in Facatativá

Figure 14 shows the spatial distribution of the temperature gradients, where the entire municipality tended to increase the average temperature by between $0.0^{\circ} \mathrm{C} /$ year and $0.03^{\circ} \mathrm{C} /$ year, with an average of $0.02^{\circ} \mathrm{C} /$ year throughout the municipality. The maximum temperature ranged between $-0.026^{\circ} \mathrm{C} /$ year and $0.05^{\circ} \mathrm{C} /$ year, influenced by the gradient determined by Venecia and La Primavera stations. The average trend of the maximum temperature for Facatativá was $0.0015^{\circ} \mathrm{C} /$ year. Finally, the minimum temperature ranged between $0.01^{\circ} \mathrm{C} /$ year and $0.07^{\circ} \mathrm{C} /$ year, with a territorial average of $0.025^{\circ} \mathrm{C} /$ year. A clear trend was observed between the minimum values presented towards the western sector of the municipality, which is higher with a mountainous relief, unlike the eastern sector where higher trends were observed in a flatter area with less dense coverage.

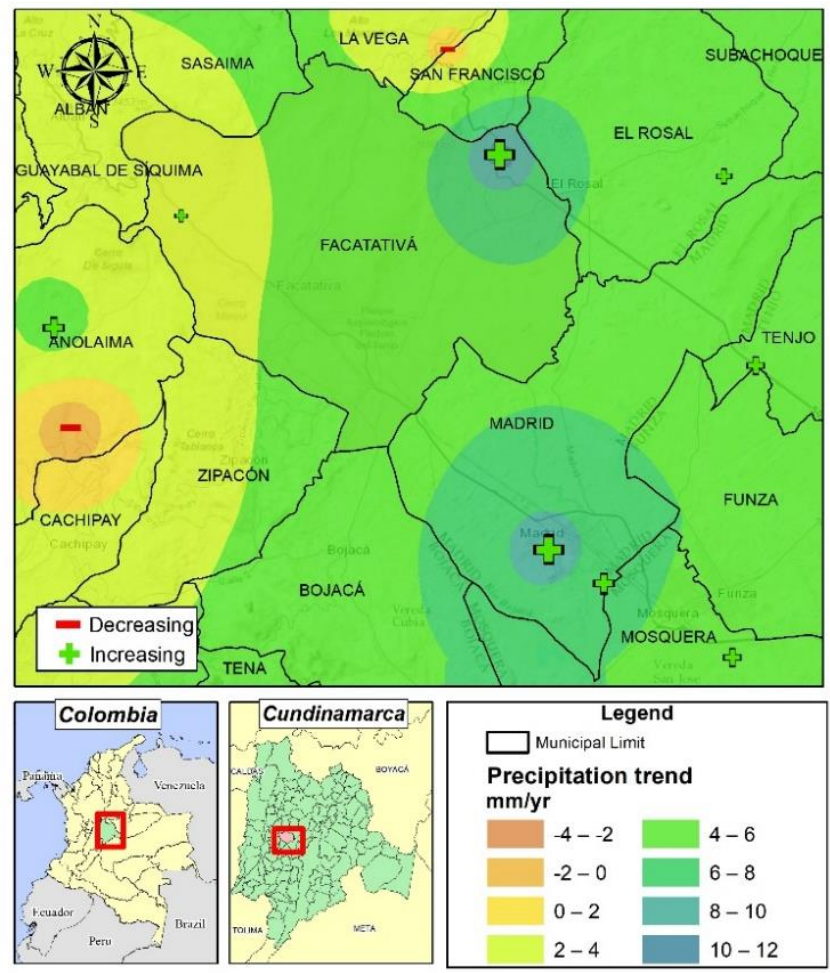

Figure 15. Precipitation trend in Facatativá

The precipitation throughout the municipality had an increasing trend, with values between 3.0 and $12.0 \mathrm{~mm} / \mathrm{year}$, with an average of $4.9 \mathrm{~mm} / \mathrm{year}$. There was an inversely proportional relationship between the total annual precipitation (Figure 4) and the trend in the precipitation variation (Figure 15), showing that the areas with higher precipitation had a lower tendency for increased rainfall, as seen in the northern zone on the border with the municipality of La Vega and the western region on the border with Albán and Anolaima. The areas with lower rainfall had higher trends, as evidenced by the southeastern zone on the border with the municipality of Madrid and the northeast zone bordering El Rosal.

The change in the magnitude of temperatures increased evapotranspiration, causing a greater exchange of gases with the atmosphere and loss of water. When the soil does not have the required amount of moisture, plants suffer water stress, which causes wilting.

Even though a trend of increasing precipitation might imply a greater availability of water, this has not occurred over the years. Rather, the phenomena that modify average conditions have meant that the effects of the phenomena related to the El Niño Southern Oscillation [3, 24] have resulted in intense and more frequent emergencies related to floods, forest fires, and landslides, which have affected this municipality and Colombia [25]; therefore, a disproportionate distribution of precipitation facilitates the development of extreme water deficits in some seasons and excess water in others.

If trends continue, by 2050, an average increase in the average temperature between $-0.008^{\circ} \mathrm{C}$ and $0.99^{\circ} \mathrm{C}$, a maximum temperature between -0.88 and $1.57^{\circ} \mathrm{C}$, and a minimum between $0.35^{\circ} \mathrm{C}$ and $2.16^{\circ} \mathrm{C}$ will be reached, while precipitation will increase by between $68.0 \mathrm{~mm}$ and $406.2 \mathrm{~mm}$. However, these values may vary depending on factors such as global policies on climate change and seasonal variability derived from ITCZ and ENSO events. 
Table 2. Temperature and precipitation trends in the analyzed weather stations

\begin{tabular}{ccccc}
\hline Weather Station Code & $\begin{array}{c}\text { Mean Temperature } \\
\text { Trend }\left({ }^{\circ} \mathbf{C} / \mathbf{y}\right)\end{array}$ & $\begin{array}{c}\text { Maximum Temperature } \\
\text { Trend }\left({ }^{\circ} \mathbf{C} / \mathbf{y}\right)\end{array}$ & $\begin{array}{c}\text { Minimal Temperature } \\
\text { Trend }\left({ }^{\circ} \mathbf{C} / \mathbf{y}\right)\end{array}$ & $\begin{array}{c}\text { Precipitación trend } \\
(\mathbf{m m} / \mathbf{y})\end{array}$ \\
\hline 2120557 & 0.0891 & 0.0854 & 0.0952 & 3.1959 \\
2120629 & -0.0042 & -0.0274 & 0.0126 & 2 \\
21201070 & - & - & - & 12.96 \\
21205420 & 0.0234 & 0.0417 & 0.0428 & 4.2671 \\
21205660 & 0.0274 & 0.0157 & 0.0274 & 3.4799 \\
21205670 & 0.0446 & 0.0596 & -0.0071 & -4.4797 \\
21205720 & 0.0299 & 0.0562 & -0.0027 & 2.6947 \\
21205770 & -0.0265 & -0.0168 & 0.0451 & 12.098 \\
21205980 & 0.0246 & 0.0505 & 0.075 & -5.527 \\
21206060 & - & - & - & 6.3067 \\
21206180 & 0.017 & 0.0229 & 0.0174 & 6.2092 \\
23065100 & 0.0233 & -0.0049 & 0.0142 & -0.6387 \\
23065120 & 0.0107 & 0.0384 & 0.0183 & 3.3333 \\
\hline
\end{tabular}

\section{CONCLUSIONS}

Facatativá has an average temperature of $12.5^{\circ} \mathrm{C}$, minimum temperatures between $2.4^{\circ} \mathrm{C}$ and $7.8^{\circ} \mathrm{C}$ and maximum temperatures between $14.0^{\circ} \mathrm{C}$ and $20.1^{\circ} \mathrm{C}$. The first half of the year is warmer than the second half. The total annual precipitation average for the municipality is $922 \mathrm{~mm} / \mathrm{year}$, with two rainy seasons: from March to June and from October to December. In the last 30 years, the average temperature has increased by between $0.0^{\circ} \mathrm{C} /$ year and $0.03^{\circ} \mathrm{C} /$ year, with an average of $0.02^{\circ} \mathrm{C} /$ year. The maximum temperature has ranged between $-0.026^{\circ} \mathrm{C} /$ year and $0.05^{\circ} \mathrm{C} /$ year, with an average of $0.0015^{\circ} \mathrm{C} /$ year. The minimum temperature has ranged between $0.01^{\circ} \mathrm{C} /$ year and $0.07^{\circ} \mathrm{C} /$ year, with a territorial average of $0.025^{\circ} \mathrm{C} /$ year. Finally, the precipitation had an increasing trend, with values between 3.0 and $12.0 \mathrm{~mm} / \mathrm{year}$, with an average of $4.9 \mathrm{~mm} /$ year.

If trends continue, by 2050 , the average temperature is expected to increase by up to $0.99^{\circ} \mathrm{C}$, the maximum temperature is expected to increase by between $-0.88^{\circ} \mathrm{C}$ and $1.57^{\circ} \mathrm{C}$, and the minimum temperature is expected to increase by between $0.35^{\circ} \mathrm{C}$ and $2.16^{\circ} \mathrm{C}$. On the other hand, precipitation will increase by between $68.0 \mathrm{~mm}$ and $406.2 \mathrm{~mm}$, as compared to the average conditions. However, this behavior also depends on seasonal variability and world policies against climate change, resulting in a certain degree of uncertainty.

\section{REFERENCES}

[1] World Meteorological Organization, 2019WMO confirms past 4 years were warmest on record | World Meteorological Organization. WMO Website, 2019. https://public.wmo.int/en/media/press-release/wmoconfirms-past-4-years-were-warmest-record, accessed on Aug. 31, 2019.

[2] García, M.C., Botero, A.P., Quiroga, F.A.B., Robles, E.A. (2012). Variabilidad climática, cambio climático y el recurso hídrico en Colombia. Revista de Ingeniería, 36: 60-64.

[3] Cai, W., Borlace, S., Lengaigne, M., van Rensch, P., Collins, M., Vecchi, G., Timmermann, A., Santoso, A., McPhaden, M.J., Wu, L.X., England, M.H., Wang, G.J., Guilyardi, E., Jin, F.F. (2014). Increasing frequency of extreme El Niño events due to greenhouse warming. Nature Climate Change, 4(2): 111-116. https://doi.org/10.1038/nclimate2100
[4] Bunclark, L., Gowing, J., Oughton, E., Ouattara, K., Ouoba, S., Benao, D., (2018). Understanding farmers' decisions on adaptation to climate change: Exploring adoption of water harvesting technologies in Burkina Faso. Global Environmental Change, 48: 243-254. https://doi.org/10.1016/j.gloenvcha.2017.12.004

[5] IPCC, 2013 Preguntas frecuentes Cambio climático 2013 Bases físicas Resumen para responsables de políticas. https://www.ipcc.ch/site/assets/uploads/2018/03/WG1A R5_SummaryVolume_FINAL_SPANISH.pdf.

[6] Díaz, G.C. (2012). El cambio climático. Ciencia y Sociedad, 2: 227-240. http://www.redalyc.org/pdf/870/87024179004.pdf.

[7] Intergovernmental Panel on Climate Change. (2014). Climate Change 2014: Mitigation of Climate Change. Cambridge University Press. https://doi.org/10.1017/cbo9781107415416

[8] Valdivia, C., Barbieri, C. (2014). Agritourism as a sustainable adaptation strategy to climate change in the Andean Altiplano. Tourism Management Perspectives, 11: 18-25. https://doi.org/10.1016/j.tmp.2014.02.004

[9] Magoni, M., Munoz, C.M. (2018). Climate change and heat waves in Colombia. Possible effects and adaptation strategies. Research for Development, 351-361. https://doi.org/10.1007/978-3-319-61988-0_27

[10] Carrera-Villacrés, D.V., Guevara-García, P.V., TamayoBacacela, L.C., Balarezo-Aguilar, A.L., Narváez-Rivera, C.A., Morocho-López, D.R. (2016). Relleno de series anuales de datos meteorológicos mediante métodos estadísticos en la zona costera e interandina del Ecuador, y cálculo de la precipitación media. Idesia, 34(3): 81-90. https://doi.org/10.4067/S0718-34292016000300010

[11] HIMAT. (1990). Técnicas estadísticas aplicadas en el manejo de datos hidrológicos y meteorológicos. Bogotá. http://documentacion.ideam.gov.co/openbiblio/bvirtual/ 009198/009198.pdf.

[12] Fries, A., Rollenbeck, R., Nauß, T., Peters, T., Bendix, J., (2012). Near surface air humidity in a megadiverse Andean mountain ecosystem of southern Ecuador and its regionalization. Agricultural and Forest Meteorology, 152: 17-30. https://doi.org/10.1016/j.agrformet.2011.08.004

[13] Vargas-García, W.C. (2020). Factibilidad de reverdecer una zona árida mediante el estudio climatológico del Desierto de Sabrinsky ubicado en el municipio de Mosquera - Cundinamarca. Universidad Católica de Colombia. https://hdl.handle.net/10983/24751. 
[14] Zambrano, B.C. (2012). Los ecosistemas semisecos del altiplano cundiboyacense, bioma azonal singular de Colombia, en gran riesgo de desaparición. Revista Mutis, 2(1): 112-145. https://doi.org/10.21789/22561498.364

[15] Jiménez García, M. (2014). Validación de la capacidad de modelo WRF "Weather Research and forecasting" para pronósticar lluvia intensa, usando el método orientado a objetos y tablas de contingencia (tesis de maestria). 162. https://repositorio.unal.edu.co/bitstream/handle/unal/54 576/Libro_Tesis_Mauricio.pdf?sequence=1\&isAllowed $=\mathrm{y}$.

[16] Taylor, G.T., Muller-Karger, F.E., Thunell, R.C., Scranton, M.I., Astor, Y., Varela, R., Ghinaglia, L.T., Lorenzoni, L., Fanning, K.A., Hameed, S., Doherty, O. (2012). Ecosystem responses in the southern Caribbean Sea to global climate change. Proceedings of the National Academy of Sciences of the United States of America 109(47): $19315-19320$ https://doi.org/10.1073/pnas.1207514109

[17] Eslava, J.A. (1991). Variación temporal de la temperatura del aire en Bogotá. Rev. Acad. Colomb. Cienc., 18(68): 65-74 https://raccefyn.co/index.php/raccefyn/issue/view/112/2 13.

[18] González, F. (2018). Planteamiento de un modelo de predicción de heladas en cultivos de rosa en la Sabana de Bogotá. Universidad Militar Nueva Granada. http://hdl.handle.net/10654/17682.

[19] Gupta, J., van der Leeuw, K., de Moel, H. (2007). Climate change: A "glocal" problem requiring "glocal" action. Environmental Sciences, 4(3): 139-148. https://doi.org/10.1080/15693430701742677

[20] Reyes-García, V., Fernández-Llamazares, Á., Guèze, M., Garcés, A., Mallo, M., Vila-Gómez, M., Vilaseca, M. (2016). Local indicators of climate change: The potential contribution of local knowledge to climate research. Wiley Interdisciplinary Reviews: Climate Change, 7(1): 109-124. https://doi.org/10.1002/wcc.374

[21] Kennedy, C. (2020). Does "global warming" mean it's warming everywhere? IOAA Climate.gov. https://www.climate.gov/news-features/climateqa/does-global-warming-mean-it's-warmingeverywhere, accessed on Jan. 02, 2021

[22] Vose, R.S., Easterling, D.R., Kunkel, K.E., LeGrande, A.N., Wehner, M.F. (2017). Ch. 6: Temperature Changes in the United States. Climate Science Special Report: Fourth National Climate Assessment, Volume I. Washington, DC. https://doi.org/10.7930/J0N29V45

[23] Bandopadhyay, S. (2016). Does elevation impact local level climate change? An analysis based on fifteen years of daily diurnal data and time series forecasts. Pacific Science Review A: Natural Science and Engineering, 18(3): 241-253. https://doi.org/10.1016/j.psra.2016.11.002

[24] Rojo-Hernández, J.D., Mesa, Ó.J., Lall, U. (2020). Enso dynamics, trends, and prediction using machine learning. Weather and Forecasting, 35(5): 2061-2081. https://doi.org/10.1175/WAF-D-20-0031.1

[25] Guarín, D. (2018). Disaster risk management in Colombia: Review of national unit for disaster risk management NUDRM. 